\title{
Panorama cywilizacji zrównoważonego rozwoju
}

\section{Wstęp}

Prehistoria zrównoważonego rozwoju wiąże się z leśnictwem niemieckim. Pojęcie to zostało wprowadzone przez Hansa Carla von Carlowitza i dotyczyło sposobu gospodarowania lasami. Zrównoważona gospodarka leśna miała polegać na tym, aby wycinać tylko tyle drzewa, ile może w to miejsce urosnąć, tak by las nigdy nie został zlikwidowany. W połowie XX wieku wrócono do tej koncepcji, ale rozszerzono ją poza sferę leśnictwa, przenosząc na światowy system ekologiczny. W ostatnim ćwierćwieczu XX wieku, pojęcie zrównoważonego rozwoju bardzo zyskało na swej popularności. W perspektywie nowego stulecia, koncepcja ta nadal jest popularną alternatywą rozwoju cywilizacyjnego świata.

Rozwój cywilizacyjny jest zarówno naszym dobrodziejstwem jak i przekleństwem. Dobrodziejstwem, bo rozwój nauki i techniki ulepsza i poprawia nasze życie, zmienia jego jakość, mamy szanse zdobywać i odkrywać świat, możemy skutecznie leczyć ludzi, poznawać nowe horyzonty i tak dalej i tak dalej. Ale jest też przekleństwem, bo prowadzi do obniżenia jakości życia, powoduje zagrożenia zdrowia psychicznego i fizycznego, katastrofy, klęski, wyniszczenie zasobów naturalnych, i inne niepożądane skutki cywilizacyjne o charakterze globalnym. Model rozwoju społeczno-gospodarczego oparty na ciągłym wzroście konsumpcji towarów i usług, paliwach kopalnych, rozwoju motoryzacji, wytwarzaniu masowo wyrobów jednorazowego użytku i kumulacji odpady, niszczy ekosystemy, od których jesteśmy zależni w naszej biologicznej egzystencji. Taki wzrost gospodarczy i rozwój cywilizacyjny, nie może trwać bez końca, bo nie zaspokoi przyszłych potrzeb rosnącej liczby ludności świata ${ }^{1}$. Poszukiwania skupiają się więc na wypracowaniu nowego, bardziej zrównoważonego modelu rozwoju naszej cywilizacji.

Historia uczy, że dotychczas znane nam cywilizacje, po osiągnięciu szczytu swojej żywotności cywilizacyjnej, traciły swój impet rozwojowy i chyliły się ku upadkowi. Stwierdza to m.in. w swojej książce „Punkt zwrotny” F. Capra a wybrane przykłady opisuje S. Kozłowski. Zob. S. Kozłowski, Przyszłość ekorozwoju, Wyd. KUL, Lublin 2005, s. 27-34; F. CAPra, Punkt zwrotny, Wyd. PIW, Warszawa 1987. 
Alternatywą dla świata, może być wspomniana wcześniej koncepcja rozwoju zrównoważonego (sustainable development). Idea ta, rozumiana jako globalna strategia rozwoju, ma na celu poprawę jakości życia i podniesienie dobrobytu ludzkości, na drodze rozwoju społeczno-gospodarczego, w warunkach skończoności i ograniczoności zasobów przyrodniczych. Jej dopełnieniem jest konieczna współodpowiedzialności i solidarności obecnych oraz przyszłych pokoleń, a także nowa forma etyki, zwana niekiedy etyką środowiskową. W tych ogólnych założeniach i celach, zrównoważony rozwój napotyka na wiele praktycznych i mentalnych problemów, które hamują, bądź wręcz uniemożliwiają efektywne wprowadzanie tej koncepcji w życie.

\section{Cywilizacja i jej rozwój}

Warunkiem przekroczenia naturalnych ograniczeń i barier przyrodniczych w rozwoju gatunku ludzkiego, było pojawienie się zdolności rozumowych człowieka. Zdolność myślenia abstrakcyjnego, wprowadziła na arenie dziejów dużo zmian i wytworzyła nowy porządek, który z czasem stanął w opozycji do natury. Tym nowym porządkiem stała się kultura, która przynależy wyłącznie człowiekowi i jest sumą doświadczenia oraz wiedzy kolektywnej, nagromadzonej i utrwalonej w pamięci społecznej ${ }^{2}$. Na jej podstawie ukształtowane zostały swoiste zasady, modele i schematy ogólnej wizji świata. Zapamiętuje ona wszystkie dane poznawcze i zapisuje normy praktyczne, etyczne, polityczne czy społeczne, które są elementami składowymi dalszego rozwoju cywilizacyjnego człowieka ${ }^{3}$. Zaistnienie kultury umożliwiło „wyrwanie się" człowieka z ryzów ewolucji biologicznej i przekazywanie wielu informacji drogą pozagenetyczną ${ }^{4}$ Tak więc dzisiaj człowiek dziedziczy cechy wspólne wszystkim istotom żyjącym (identyczność biochemiczna) oraz to co powstało w wyniku ludzkiej działalności (kultury) ${ }^{5}$, czyli można stwierdzić, że „...człowiek żyje w kulturze nosząc w sobie przyrodę" ${ }^{\text {. }}$. Jest to podstawowy wyznacznik składający się na rozwój cywilizacyjny.

Kultura stała się specyficzną własnością gatunku ludzkiego i pociągnęła za sobą dalszą intelektualizację oraz humanizację natury ${ }^{7}$. Z czasem zaś doprowadziła do za-

\footnotetext{
Por. Kultura, w: Nowa Encyklopedia Powszechna PWN, t. 3, Wyd. PWN, Warszawa 2004, s. 716. Por. S. ZięBA, Kryzys ekologiczny. Realność czy utopia, „Człowiek i Przyroda”, 1995, nr 3, s. 24.

Por. W. J. H. Kunicki-Goldfinger, PIW, Warszawa 1993, s. 64

H. CyRZAN, Kim jest cztowiek? Ekologiczne implikacje nowego spojrzenia na ewolucję (człowieka), w: Ochrona środowiska e filozofii i teologii, prac. zbior. pod red. J. M. Dołegi i J. W. Czartoszewskiego, Wyd. ATK, Warszawa 1999, s. 54.

6 E. Morin, Zagubiony paradygmat - natura ludzka, tłum. R. Zimand, PIW, Warszawa 1977, s. 36.

7 Por. F. AdAMSKI, Kultura między sacrum a profanum, w: Człowiek - Wychowanie - Kultura, pod red. F. Adamski, Kraków 1993, s. 201.
} 
istnienia nowego środowiska życia i rozwoju człowieka ${ }^{8}$. Systematyczne, świadome i celowe przekształcanie oraz uzupełnianie przyrody, doprowadziło w konsekwencji do pojawienia się nowej przestrzeni bytowej, którą zwykło się określać mianem „środowiska społeczno-przyrodniczego”. Należy przez to określenie rozumieć całokształt warunków i czynników w których egzystują istoty żywe. Środowisko to jest zespołem warunków koniecznych i wystarczających by zaistniało życie na ziemi i by mogło się rozwijać oraz by zaistniał człowiek i mógł się rozwijać. Do dalszego rozwoju człowieka, potrzebnych jest wiele elementów naturalnych, ale i artefaktów, elementów antropogenicznych ${ }^{9}$. Stały przyrost tych elementów antropogenicznych jest efektem rozwoju nauk ścisłych i techniki. To właśnie wiedza, technika i technologia, są wskaźnikami opanowania przez ludzi sił przyrody i wykorzystania jej bogactw w celu zaspokojenia różnych ludzkich potrzeb. W taki sposób zrodziła się cywilizacją.

W przeszłości używano zamiennie terminów „kultura” i „cywilizacja”. Aktualnie pojęcie „kultura” używane jest na określenie dorobku raczej duchowego, niż materialnego ${ }^{10}$. Natomiast przez „cywilizację” rozumiemy poziom rozwoju społeczeństwa w danym okresie historycznym, który charakteryzuje się określonym poziomem kultury materialnej, stopniem opanowania środowiska naturalnego, nagromadzeniem instytucji społecznych ${ }^{11}$. Cywilizacja stanowi najwyższy poziom organizacji społeczeństw, z którym jednostki identyfikują się. Istotnym wskaźników poziomu kultury materialnej, jest umiejętność wykorzystywania i kształtowania przyrody. Czyli można stwierdzić, że współcześnie pod pojęciem „cywilizacja”, należy rozumieć typ kultury zaawansowanej społecznie, materialnie ale i ideologicznie, charakterystyczny dla tzw. społeczeństw cywilizowanych (złożonych), przeciwstawianych społeczeństwom niecywilizowanym (prostym) oraz jako określenie najwyższego w systemie ewolucji ludzkości stadium rozwoju kultury.

8 Por. J. Łapiński, „Pradzieje” Homo technicus, „Studia Philosophiae Christianae”, 1999 (35), nr 2, s. 165-166; Z. Hull, Filozoficzne podstawy ekorozwoju, „Zeszyty Problemowe Postępów Nauk Rolniczych" 1992, z. 401, s. 31-32.

9 W środowisku tym mieszczą się elementy naturalne (strukturalne elementy środowiska): atmosfera, hydrosfera, litosfera, kosmosfera i biosfera oraz elementy sztuczne wytworzone przez człowieka - antroposfera. Termin ten oznacza człowieka i jego całościowo, tzn. w aspekcie czasowym i przestrzennym, ujęte dzieło. Antroposfera tworzy środowisko społeczne, w którym człowiek przychodzi na ten świata, rozwija się i umiera. Zasadnicze elementy tego środowiska to: nauka, technika, sztuka i religia. Inne nazwy używane na zaakcentowanie tylko niektórych aspektów tego środowiska, to: środowisko kulturowe, techniczne, cywilizacyjne, religijne, itp Por. J. M. DoŁĘGA, Koncepcja sozologii systemowej, Wyd. UKSW, Warszawa 2001, s. 127 - 142; tenże, Problematyka ochrony środowiska społeczno-przyrodniczego w sozologii i ekofilozofii, w: Ochrona środowiska w filozofii i teologii, pod. red. J. M. Dołęga, J. W. Czrtoszewski, Wyd. ATK, Warszawa 1999, s. 15; Antroposfera w: Mały słownik antropologiczny, red. naukowy T. Bielicki, Wyd. PWN, Warszawa 1969, s. 85-86.

10 Zob. Kultura w: Nowa Encyklopedia PWN..., dz. cyt., s. 716.

${ }_{11}$ Por. Cywilizacja w: Wikipedia, http://pl.wikipedia.org/wiki/Cywilizacja, (04.08.06r). 
Dzięki cywilizacji naukowo-technicznej, ludzkość zastąpiła bezpośrednie działanie mechanizmów biologicznych, stworzonym przez siebie systemem rozwoju społeczno-gospodarczego. To doprowadziło do pojawienia się wielu niebezpieczeństw, a nawet perspektywy samozagłady ludzkości ${ }^{12}$. Źródła zagrożeń ekologicznych i powstanie barier cywilizacyjnych, należy łączyć z niekontrolowaną dążnością człowieka do zaspokajania nowych potrzeb cywilizacyjnych kosztem realizacji potrzeb biologicznych i społecznych, przy najmniejszych nakładach finansowych. Znane w historii różne systemy cywilizacyjne ginęły nagle, właśnie na skutek wyczerpywania się zasobów, lub zamierały powoli na skutek stagnacji, która była efektem niezdolności do uczenia się i w konsekwencji niezdolności przystosowania się do zmienionych warunków otoczenia.

Sądzę jednak, że regresyjne, niekorzystne zmiany cywilizacyjne można powstrzymać, pod warunkiem, że zastosujemy taki model rozwoju, który będzie godził prawa ekologiczne $\mathrm{z}$ racjonalnymi i uzasadnionymi oczekiwaniami ludzi żyjących w konkretnym miejscu i określonym czasie. Potwierdzeniem tej tezy może być coraz częściej obserwowany fakt, że w programach i strategiach gospodarczych, politycy częściej zaczynają się odwoływać do koncepcji „zrównoważonego rozwoju" aniżeli do postępu technicznego czy gospodarczego ${ }^{13}$. Koncepcja ta zakłada dalsze istnienie przyrody i cywilizacji oraz sukcesywną poprawę jakości życia współczesnych i przyszłych pokoleń. Z poprawą jakości życia i rozwoju, ściśle łączy się kwestia ochrony przyrody. Chodzi w tym działaniu o utrzymanie takich parametrów środowiska przyrodniczego, które „...umożliwiając osiągnięcie dotychczasowych celów rozwoju (stały wzrost dobrobytu, komfort życia, konsumpcja itp.) zapewniają zarazem ochronę człowieka i ważnych dla niego ekosystemów przed biologiczną degradacją i zagładą" ${ }^{\prime 14}$. Chcąc wejść na tę drogę takiego rozwoju cywilizacyjnego, ludzkość musi zmienić dotychczasowy styl rozwoju oparty tylko na „wzroście” i dostosować system społeczno-gospodarczy do naturalnych możliwości środowiska przyrodniczego.

Jesteśmy przekonani, że rozwój naszej cywilizacji (cywilizacji euro-atlantyckiej) bazuje na przyroście wiedzy, innowacjach technicznych i kreowanych potrzebach materialnych ${ }^{15}$. Są to główne prerogatywy tegoż rozwoju. Stają one w opozycji do kultury, którą, jak wspomniałem wcześniej, utożsamia się bardziej ze sferą war-

12 Por. Z. PiąTeK, Człowiek jako podmiot zrównoważonego rozwoju: kontrowersje filozoficzno-spoleczne, w: Zrównoważony rozwój. Od utopii do praw człowieka, pod red. A. Papuziński, Oficyna Wyd. Branta, Bydgoszcz 2005, s. 17.

13 Por. R. Bonkowski, Cywilizacja, technika, ekologia. Wybrane problemy rozwoju cywilizacyjnego u progu XXI wieku, Uczelniane Wydawnictwo Naukowo Dydaktyczne, Kraków 2001, s. 71.

14 Z. Huld, Dylematy i wymiary ekorozwoju, „Postępy Nauk Rolniczych”, 1993, nr 3, s. 7.

15 Za: Cywilizacja, w: Nowa Encyklopedia Powszechna PWN, t. 2, Wyd. PWN, Warszawa 2004, s. 342 . 
tości duchowych, estetycznych czy moralnych. W związku z powyższym, logicznym i uzasadnionym jest przyjęcie „zrównoważonego rozwoju” za alternatywny model dalszego postępu cywilizacyjnego. Idea ta bowiem, mieści i godzi w sobie zarówno rozwój materialny, jak i postęp kulturowy. Konstruując w oparciu o jej założenia dalsze strategie i plany globalnego rozwoju cywilizacyjnego, mamy poważną szansę wyeliminować zagrożenia hamujące i negujące dalszy rozwój gospodarczy, kulturowy i cywilizacyjny.

\section{Alternatywa rozwoju cywilizacyjnego}

Angielskie określenie sustainable development, w polskiej literaturze przedmiotu funkcjonuje pod różnymi zwrotami: zrównoważony rozwój, trwały rozwój, rozwój samopodtrzymujący się. Często także występuje pod pojęciem ekorozwo$j u^{16}$. Pojecie zrównoważonego rozwoju, kształtowało się w kontekście prac międzynarodowego gremium ONZ. Oficjalnie koncepcję zrównoważonego rozwoju - rozwijaną i udoskonalaną od Konferencji w Sztokholmie ${ }^{17}$ w roku 1972 - przyjęto do realizacji na „Szczycie Ziemi”, który odbył się w czerwcu 1992 roku w Rio de Janeiro. Przyjęto wówczas dwa podstawowe dokumenty ${ }^{18}$ : Deklarację z Rio - będącą ogólną filozofią zrównoważonego rozwoju i Agendę 21 - dokument przedstawiający sposoby, zasady i mechanizmy praktycznego wprowadzania założeń tej koncepcji w życie.

Koncepcja ekorozwoju proponuje wiele nowych rozwiązań odbiegających od tradycyjnie przyjmowanych i realizowanych założeń rozwoju gospodarczego, technicznego czy społecznego. Chce w harmonijnej całości pogodzić różne porządki: ekologiczny, społeczny, gospodarczy, techniczno-technologiczny, kulturowy i aksjologiczny. Więcej, włącza środowisko przyrodnicze do rozwoju społeczno-gospodarczego regionu, kraju czy w ujęciu globalnym całego świata ${ }^{19}$. Analizując te założenia i cele, można zaryzykować stwierdzenie, że zrównoważony rozwój nie jest jakąśs zupełnie nową filozofią światowego ładu społeczno-gospodarczego, którą rozwinięte państwa wypracowały pod koniec XX wieku. Jest to koncepcja,

$16 \mathrm{~W}$ prawie ekologicznym utrwaliło się pojęcie zrównoważonego rozwoju. Obok niego istnieje też powszechnie używane pojęcie ekorozwoju. Terminy te są często używane zamiennie. Również i w tym artykule będę posługiwał się zamiennie tymi terminami.

17 Szerzej: R. PAczuski, Prawo ochrony środowiska. (Stan prawny na dzień 30 września 2000), Oficyna Wyd. Branta, Bydgoszcz 2000, s. 32-37; S. Kozlowski, Ekologiczne problemy przyszłości świata i Polski, Wyd. PWN, Warszawa 1998, zał. 1: Deklaracja końcowa Konferencji Sztokholmskiej ONZ na temat: Środowisko naturalne człowieka.

${ }_{18}$ Dokumenty te zostały przetłumaczone na jęz. polski i opublikowane w: Dokumenty końcowe Konferencji Narodów Zjednoczonych „Środowisko i Rozwój”. Rio de Janeiro, 3-14 czerwca 1992. Szczyt Ziemi, Instytut Ochrony Środowiska, Warszawa 1993.

19 H. ŻukowsKa, Ekonomiczne aspekty ochrony środowiska naturalnego. (Na przykładzie województwa lubelskiego), Wyd. Uniwersytetu Marii Curie-Skłodowskiej, Lublin 1996, s. 201. 
według której człowiek żył na początku naszej cywilizacji, w harmonii i ładzie z przyrodą i innymi ludźmi, a teraz tylko ją na nowo odkrywa ${ }^{20}$. Odkrycie to polega m.in. na zrozumieniu różnic, pomiędzy "rozwojem” a „wzrostem”.

Proces kierunkowych, rozciągniętych w czasie zmian, w trakcie którego obiekty (układy) przechodzą od form lub stanów prostszych do coraz to bardziej złożonych i zaawansowanych, określa się mianem „rozwoju”"21. Tak określony rozwój, jest często w języku potocznym mylony z „postępem” i „wzrostem”. Idea postępu jest równie stara jak cywilizacja i w znaczeniu potocznym oznacza poprawę wcześniejszego stanu rzeczy, a więc zakłada zmianę na lepsze w przeciwieństwie do regresu. W naszej cywilizacji funkcjonuje paradygmat „postępu naukowo technicznego", który na bazie linearnego i kwantytatywnego modelu rozwoju zakłada, że zwiększająca się liczba odkryć naukowych i wynalazków technicznych, wiedzie prostą drogą do zwiększonej i ulepszonej ilości towarów, a co za tym idzie, do wzrostu globalnego dobrobytu ${ }^{22}$. Pojawia nam się w tym kontekście trzeci termin: „wzrost”, który implikuje przede wszystkim zmiany ilościowe, pomijając przewartościowania jakościowe.

Idea sustainable development zakłada pogodzenia i połączenia w jedną kompatybilną całość, dwóch sprzecznych i pozornie antagonistycznych pojęć „wzrostu” i „,rozwoju”. „Wzrost” dąży do przyrostu materii, natomiast „rozwój” do pełniejszego, większego, bądź lepszego stanu przez rozszerzenie lub realizację określonych możliwości ${ }^{23}$. Mając na względzie tę różnice, koncepcja ta proponuje kontynuację rozwoju cywilizacyjnego razem $z$ otoczeniem - społecznym i przyrodniczym ${ }^{24}$. Na tym polega swoista nowość i oryginalność tego podejścia.

W analizach idei „zrównoważonego rozwoju”, pojawia się troska o obecne ale i o następne pokolenia. Chodzi tu o uświadomienie prostej zasady, że po nas przyjdą inne pokolenia, a my nie możemy żyć na ich koszt. Musimy zrezygnować $\mathrm{z}$ naszego egoizmu i egalitaryzmu gatunkowego. Prawda ta, zapisana jest $w$ wielu określeniach ekorozwoju. Jeżeli przyjmiemy, że w powszechnym i obiegowym rozumieniu „ekorozwój” $\mathrm{i}$ „Zrównoważony rozwój”, to to samo, to wówczas możemy też zdefiniować zrównoważony rozwój jako „...programem restrukturyzacji powiązań ekonomicznych społecznych i technicznych, mającej na celu ochronę

20 A. Hutniczak, I. Jurzak, Analiza wybranych kwestii dotyczacych kapitalu ludzkiego w odniesieniu do rozwoju zrównoważonego i trwalego oraz do otaczającej nas rzeczywistości, w: Zrównoważony rozwój a ochrona śro dowiska. Międzywydziałowa konferencja Kół Naukowych. Bielsko Biała 18 maja 2005 r. materiały konferencyjne, red naukowa B. Więzik, Wyd. Akademi Techniczno Humanistycznej, Bielsko Biała 2006, s. 84.

${ }_{21}$ Por. Rozwój, w: Nowa Encyklopedia Powszechna PWN, t. 3, Wyd. PWN, Warszawa 2004, s. 716.

22 R. Bonkowski, Cywilizacja, technika, ekologia..., dz. cyt., s. 12.

23 Por. J. Machowski, Ochrona środowiska. Prawo i zrównoważony rozwój, (Stan prawny na dzień 1 stycznia 2003 r.), Wyd. Akademickie „Żak”, Warszaw 2003, s. 100-101.

${ }_{24}$ Por. L. Michnowski, Ekorozwój-nadzieja, konieczność, szansa, „Nauka”, 1994, nr 1, s. 145. 
przyrody i środowiska człowieka na użytek obecnego i przyszłych pokoleń, oraz w uznaniu wartości przyrody jako takiej. Obejmuje on długotrwałe wykorzystanie odnawialnych zasobów naturalnych, efektywną eksploatację nieodnawialnych źródeł energii, utrzymanie stabilności procesów ekologicznych i ekosystemów, zachowanie i polepszenie stanu zdrowia ludzi, bezpieczeństwa pracy i dobrobytu"25. Także Konrad Waloszczyk rozumie zrównoważony rozwój jako koncepcję, która jest w stanie zapewnić nam dalszy rozwój i dobrobyt, ale na całkowicie odmiennych i przeciwstawnych warunkach do obecnie panującej koncepcji dobrobytu, opartej na materialistycznie pojmowanym wzroście gospodarczym. Ta linia rozwoju jest zastąpiona ideą wzrostu równoważącego gospodarkę z możliwościami i wartościami środowiska oraz z troską o zapewnienie dobrobytu wszystkim ludziom, społecznościom lokalnym i regionalnym i utrzymanie potencjału rozwojowego dla następnych pokoleń ${ }^{26}$. Jest to więc „koncepcją dobrobytu harmonizującą wartości ekonomiczne, ekologiczne i społeczne". ${ }^{27} \mathrm{~W}$ tym duchu koncepcję zrównoważonego rozwoju ujmuje również Franciszek Piontek. Określa ją jako: „...trwałą poprawę życia współczesnych i przyszłych pokoleń przez kształtowanie właściwych proporcji między trzema rodzajami kapitału: ekonomicznym (E), ludzkim (L) i przyrodniczym (P)"28. Podobna definicja została zaakceptowana na Szczycie Ziemi w Johanesburgu w 2002 r., gdzie w przyjętej Deklaracji w Sprawie Zrównoważonego Rozwoju przyjęto chęć wprowadzenia tej zasady w życie.

\section{Mentalno-świadomościowe trudności ze zrównoważonym rozwojem}

Istnieją realne bariery, które utrudniają bądź wręcz uniemożliwiają wprowadzenie tej teorii w praktykę światowej gospodarki i rozwoju społeczno-kulturowego, elementów składających się na cywilizację. Na wspomnianym powyżej Szczycie Ziemi w Johanesburgu, krytycznie oceniono praktykę dziesięcioletniego wprowadzania w życie tej idei. Stwierdzono tam, że bez głębokiej przemiany świadomościowej, bez reformy obecnego systemu globalnego zarządzania gospodarką i środowiskiem przyrodniczym oraz bez zmiany priorytetów światowej ekonomii, zrównoważony rozwój może ponieść fiasko realizacyjne ${ }^{29}$. Ten stan

25 Definicja ta została sformułowana w 1990 r. przez polskich i amerykańskich uczonych i zapisana w dokumencie: Środowisko a rozwój Polski. Deklaracja ekorozwoju, Białystok 1990. Cyt. za: S. KozŁowski, W drodze do ekorozwoju. PWN, Warszawa 1997, s. 154.

${ }^{26}$ Por. K. WAloszczYк, Ku ekorozwojowi, w: Zrównoważony rozwój. Zbiór opracowań, red. tech. K. Kuzdrzał, Wyd. Handlowe GRAF, Warszawa 2004, s. 14.

27 Tamże, s. 19.

28 Cyt za: A. Hutniczak, I. Jurzak, Analiza wybranych kwestii dotyczacych kapitalu ludzkiego w odniesieniu do rozwoju zrównoważonego..., dz. cyt., s.88.

${ }_{29}$ Por. J. Mizak, Szczyt w Johanesburgu, Departament Współpracy z Zagranicą, Ministerstwo Środowiska, Warszawa 2002, w: http://www.unic.unorg.pl/johanesburg/, 16.03.2004, godz. 17.00 
obaw, potęguje słabe zaangażowanie rządów najbardziej rozwiniętych państw świata, brak koordynacji politycznej i słabe, a właściwie żadne, finansowanie tej koncepcji.

Problemem zasadniczym jest brak rzeczywistej i autentycznej woli politycznej. Zdzisław Sadowski widzi potrzebę, jak najszybszego ukonstytuowania układu instytucjonalnego, który byłby zdolny do ustalenia, promowania i realizowania jednolitej polityki rozwoju, opartej na zasadnych postulatach ekorozwoju ${ }^{30}$. Inną kwestią jest nieskuteczna polityka wyrównywania poziomów życia i możliwości rozwojowych poszczególnych obszarów naszego Globu. Nie można zapominać, że potrzeba, bieda, brak własności i kapitału oraz wiedzy, prowadzą do nieracjonalnego i niezrównoważonego sposobu zużywania zasobów przyrodniczych przez państwa najbiedniejsze. Bieda wpływa na stan środowiska ale i odwrotnie, zły stan środowiska potęguje biedę ${ }^{31}$. Postępująca globalizacja, w której upatrywano szans dla zrównoważonego rozwoju, szybko okazała się swoistą „fikcję", którą zaczęto traktować jako zespół działań służących utrwaleniu hegemonii wielkich światowych koncernów i bogatych państw, w tym USA i Europy. Rozwijając bez zasadniczych zmian obecną politykę gospodarczą dążącą do utrzymania wysokiego poziomu konsumpcji, bogate społeczeństwa wydają się nie dostrzegać potęgujących się zagrożeń ekologicznych, bądź zagrożenia te przesuwać do krajów ubogich poprzez legalny - a jeszcze bardziej - nielegalny eksport zanieczyszczeń i przestarzałych technologii. Nie ma powszechnej świadomości, że o ile trudności gospodarcze i polityczne mogę być przezwyciężone w ciągu życia jednego pokolenia, skutki katastrofy ekologicznej będą trwały znacznie dłużej dotykając dziesiątki przyszłych pokoleń.

Innym źródłem utrudnień w procesie realizacji zrównoważonego rozwoju, jest dominujący w społeczeństwach wysokorozwiniętych system wartości ${ }^{32}$. Przeważa w tym systemie chęć posiadania nad sposobem „bycia”"33. Istotną przyczyną hamującą wdrażanie zrównoważonego rozwoju w skali globalnej, jest uprzedmiotowienie pragnień ludzi $i^{34}$. Poza tym, rozwój społeczno-ekonomiczny i postęp techniczny, znacznie wyprzedzają intelektualny i psychiczny rozwój człowieka ${ }^{35}$. Są to problemy

30 Z. SADowsKI, Dezyderat trwatego rozwoju $i$ warunki jego spetnienia. (Tezy), w: Filozoficzne i społeczne uwarunkowania zrównoważonego rozwoju, pod red. A. Pawłowski, Monografie nr 16, PAN, Komitet Ochrony Środowiska, Lublin 2003, s. 14.

31 K. WALoszczyK, Ku ekorozwojowi, w: Zrównoważony rozwój..., dz. cyt., s. 17.

32 Por. R. FrI, Historia naturalna a wiek XXI, w: Oblicza Ziemi. Zagrożenia i nadzieje, praca zbior. pod red. D. Botkina i in., (Raport the Smithsonian Institution i National Geographic), „G+J RBA", Warszawa 2001, s. 244-245

33 J. STACEwICZ, Cywilizacyjno-kulturowe uwarunkowania ekorozwoju, w: Sterowanie ekorozwojem. Teoretyczne aspekty ekorozwoju, pod red. naukową B. Poskrobka, t. I, Wyd. Politechniki Białostockiej, Białystok 1998, s.112.

${ }_{34}$ S. Kozlowski, Ogólne uwarunkowania ekorozwoju, w: Sterowanie ekorozwojem..., dz. cyt. t. I, s. 91.

35 Por. M. Czyż, Rozwój zrównoważony a przemiany cywilizacyjne, w: Ekologia a transformacje cywilizacyjne na przełomie wieków, prac. zbior. pod red. S. Zięby i Z. Wróblewskiego, Zakład Ekologii Człowieka KUL, Lublin 2000, s. 83. 
natury moralno-etycznej, wynikające $z$ aktualnie dominującego wzorca rozwoju cywilizacyjnego.

\section{Wskazania ważne dla zrównoważonej cywilizacji ${ }^{36}$}

Motorem przekształcającym dotychczasową cywilizację w cywilizację zrównoważonego rozwoju, powinna być zmiana fundamentalnych postaw i zachowań człowieka ery przemysłowo-technicznej, na rzecz postaw i zachowań człowieka ery ekologicznej. Znaczy to, że w perspektywie czasowej zmianie ulec muszą standardy życia właściwe cywilizacji konsumpcyjnej ${ }^{37}$. Osiągnięcie tego przewartościowania, jest kluczową kwestią dla rozwoju zrównoważonego naszego świata. Teoretyczne i praktyczne działania zmierzające do promowania takiego rozwoju, wymagają podjęcia szeregu skoordynowanych działań o charakterze naukowym, prognostycznym, decyzyjnym, ekonomicznym, technicznym, ekologicznym, ale także o charakterze świadomościowym i edukacyjnym czy wręcz etycznym. W praktyce oznacza to przełożenie wyrafinowanych teorii i politycznych deklaracji na konkretne zachowania ludzi w wymiarze indywidualnym i społecznym.

Wiele utrudnień, które pojawiły się na drodze realizacji zrównoważonego rozwoju, jest związanych z brakiem wystarczającego finansowania tego procesu. Zatem zasadniczym warunkiem dla optymalnego funkcjonowania koncepcji ekorozwoju na obecnym poziomie wdrażania, jest właściwe finansowanie. Można je zapewnić poprzez wprowadzenie odpowiednich opłat i podatków ekologicznych, a także na drodze ograniczania wydatków w innych sektorach gospodarki, np. przemyśle zbrojeniowym i przesunięciu tak zaoszczędzonych funduszy, na potrzeby wdrażania zrównoważonego rozwoju ${ }^{38}$. Prawidłowe funkcjonowanie zrównoważonego rozwoju nie zależy jednak wyłącznie od przeznaczonych na ten cel środków finansowych, ale od świadomości i społecznej akceptacji. Pomocne w tym względzie, mogłoby być powołania organizacji międzynarodowej, która w swojej gestii podejmowałaby decyzje polityczne i organizacyjne w odniesieniu do ogólnoświatowych problemów związanych z zagrożeniami środowiskowymi.

36 Powyższa problematyka, szerzej została omówiona w moim artykule pt.: Trudności i możliwości wdrażania koncepcji zrównoważonego rozwoju (Aspekty świadomościowe i praktyczne), w: Wokół biofilozofii Kazimierza Kloskowskiego. Wybrane zagadnienia, pod red. M. Bała, Wyd. Bernardinum, Pelplin 2004, s. 195-214.

37 Szerzej na ten temat patrz: O. Hronec, Ekorozwój - jedyna droga w przyszłość, Materiały z X Ogólnopolskiego Forum Ekologii Wsi, „Miasto i wieś wspólnie na drodze do ekorozwoju, CEEW, Krosno 2000, s. 107; B. PionTeK, Jakość życia i sposoby jej mierzenia w strategii wzrostu gospodarczego i zrównoważonego rozwoju, „Problemy Ekologii” 1999, nr 6, vol. 3, s. 120-121.

38 Por. Instrumenty ekorozwoju. Prawne, ekonomiczne, finansowe, „EKOFinanse”, 2001, nr 4(71), s. 15-16. 
W procesie budowania cywilizacji zrównoważonego rozwoju, ważnym zadaniem jest m.in..$^{39}$

- promowanie informacji i wiedzy ludzkiej, indywidualnej i zbiorowej,

- powiązanie ekospołecznej użyteczności pracy jednostek i organizacji z wielkością dochodów uzyskiwanych w wyniku tej pracy,

- opanowanie umiejętności długookresowego prognozowania oraz wymiernego wartościowania pracy i skutków innych zmian w otoczeniu,

- stworzenie podstaw (również w wymiarze informacyjnym) elastycznego i wyprzedzającego zagrożenia ekospołecznie użytecznego gospodarowania,

- opanowanie umiejętności rozpoznawania stanu jakości życia na podstawie wiedzy ekologicznej,

- opanowanie umiejętności sterowania procesów zmian w przyrodniczym środowisku człowieka.

Powyższe zadania, wraz z założeniami ery ekologicznej, stanowią punkt wyjścia dla wypracowywanie szczegółowych strategii rozwojowych. Strategie takie, muszą uwzględniać też potrzebę ekologizacji gospodarki, połączoną z ochroną środowiska przyrodniczego ${ }^{40}$. Na obecnym poziomie rozwoju cywilizacyjnego, praktycznie nie występuje juź środowisko naturalne. Istnieje natomiast środowisko przyrodnicze, które należy rozumnie kształtować, zgodnie z odwiecznymi prawami przyrodniczymi. Spelniając ten podstawowy warunek, istnieje szansa dalszego rozwoju i współistnienie: przemysłu - środowiska przyrodniczego - człowieka ${ }^{41}$. Dotychczas jednak społeczeństwa światowe preferują ekonomizację środowiska, polegającą na ochronie środkami ekonomicznymi i technicznymi. Wszelkie podmioty gospodarcze chcąc wdrażać w swoje procesy wytwórcze zrównoważony rozwój, powinny dostosować się do następujących wymagań:

- ograniczyć zużycie nieodnawialnych zasobów przyrody aż do ich zerowego wykorzystania,

- wykorzystywać zasoby odnawialne, ale suma netto ich wykorzystania i regeneracji nie może wzrastać,

- opanować emisję szkodliwych substancji na poziomie nie wyższym niż zdolność absorpcyjna przyrody,

— zmniejszyć obciążenie środowiska przez substancje trudno rozkładalne aż do całkowitego ich wyeliminowania,

- ograniczyć zużywanie powierzchni do poziomu ekologicznie nieszkodliwego,

39 Por. Opracowanie systemu wskaźników oceny efektywności..., dz. cyt., s. 99; także: L. Michnikowski, Ekorozwój jako forma wspólżycia, „Wieś i Państwo”, 1992, nr 2.

40 H. Żukowska, Ekonomiczne aspekty ochrony środowiska naturalnego. (Na przykładzie województwa lubelskiego), Wyd. Uniwersytetu Marii Curie-Skłodowskiej, Lublin 1996, s.201.

${ }^{41}$ Por. J. Bender, Biosfera a cywilizacja. Europa - synonim postępu, Wyd. Drukarnia Prodruk, Poznań 2003, s. 191-192. 
- unikać dużych ryzyk, których skutki wiążą się z nieodwracalnymi szkodami w ekosystemach i systemach społecznych, których nie można oszacować,

- zachować maksymalną różnorodność gatunkową, a tym samym zdolność funkcjonowania systemów ekologicznych i łańcuchów pokarmowych,

- wykształcić sposoby życia i konsumpcji chroniące środowisko,

— właściwie ukształtować naturalną i kulturową przestrzeń życia człowieka ${ }^{42}$. Z praktycznego punktu widzenia istotne też są wszelkie działania gospodarcze ograniczające energochłonności i materiałochłonności przemysłu i przetwórstwa surowców, pozwalające oszczędnie gospodarować przestrzenią i ograniczać rozwój infrastruktury komunikacyjnej oraz ograniczać zagrożenia przemysłowe. Ocenę obecnych zagrożeń i kierunki proponowanych działań zaradczych w tym względzie, przedstawia poniższe tabela ${ }^{43}$.

\section{Propozycja działań dla zrównoważonego rozwoju}

\begin{tabular}{|c|c|c|c|}
\hline L.p & Zadania & Ocena sytuacji & Propozycje zadań \\
\hline 1. & $\begin{array}{l}\text { Ograniczenie } \\
\text { energochłon- } \\
\text { ności }\end{array}$ & $\begin{array}{l}\text { Z zasobów nieodnawial- } \\
\text { nych zabrano w } 1995 \mathrm{r} \text { aż } \\
9300 \text { Mtoe }^{*} \text {, powodując } \\
\text { zmiany klimatyczne, kra- } \\
\text { jobrazowe i społeczne. }\end{array}$ & $\begin{array}{l}\text { - stabilizacja zużycia energii w krajach } \\
\text { wysoko uprzemysłowionych, } \\
\text { - wprowadzenie podatku od energii, } \\
\text { - opanowanie nowych bezpiecznych źródeł } \\
\text { energii, np. solarnej }\end{array}$ \\
\hline 2. & $\begin{array}{l}\text { Ograniczenie } \\
\text { materialochłon- } \\
\text { ności }\end{array}$ & $\begin{array}{l}\text { Przepływ materiałowy } \\
\text { powoduje katastrofę } \\
\text { odpadową }\end{array}$ & $\begin{array}{l}\text { - } \text { redukcja wkładu materiałowego } \\
\text { - podniesienie cen deponowania odpadów } \\
\text { - } \text { zamykanie obiegu materiałów (recykling) }\end{array}$ \\
\hline 3. & $\begin{array}{l}\text { Oszczędna } \\
\text { gospodarka } \\
\text { przestrzenią }\end{array}$ & $\begin{array}{l}\text { Kurczenie się powierzchni } \\
\text { gruntów rolnych } \\
\text { Postępująca dewastacja } \\
\text { krajobrazu }\end{array}$ & $\begin{array}{l}\text { - ochrona i rekultywacja terenów rolnych, } \\
\text { - wyłączenie z użytkowania ekologicznych } \\
\text { terenów kompensacyjnych i krajobrazowych, } \\
\text { - wprowadzenie podatku od zabudowania } \\
\text { gruntów, } \\
\text { - ustanowienie funduszu odnowy krajobrazu, }\end{array}$ \\
\hline 4. & $\begin{array}{l}\text { Ograniczenie } \\
\text { rozwoju } \\
\text { infrastruktury } \\
\text { komunikacyjnej }\end{array}$ & $\begin{array}{l}\text { Obecne trendy rozwoju } \\
\text { infrastruktury komunika- } \\
\text { cyjnej powodują degrada- } \\
\text { cję miast i krajobrazu }\end{array}$ & $\begin{array}{l}\text { - przyjęcie „wariantu zerowego” w plano- } \\
\text { waniu sieci polączeń komunikacyjnych, } \\
\text { - wprowadzenie założeń ekoefektywności } \\
\text { komunikacji publicznej }\end{array}$ \\
\hline
\end{tabular}

42 E. Kośmicki, Środowiskowe dylematy ekorozwoju a przyszlość polskiego rolnictwa, „Ekonomia i Środowisko", 1997, nr 1(10), s. 25.

43 Zadania realizacyjne przedstawia w schematyczny sposób w swoim artykule S. Kozlowski. Zamieszczona w pracy tabelka, jest wzorowana na powyższym artykule. Zob.: S. Kozłowski, Zrównoważony rozwój - wyzwanie przyszłości, „Człowiek i Przyroda” 1996, nr 5, s. 19-21. 


\begin{tabular}{|c|c|c|}
\hline $\begin{array}{l}\text { Ograniczenie } \\
\text { zagrozen prze- } \\
\text { mysłowych }\end{array}$ & $\begin{array}{l}\text { Narastające zagrożenia } \\
\text { związane } z \text { awariami prze- } \\
\text { mysłowymi }\end{array}$ & $\begin{array}{l}\text { - przyjęcie zasad: } \\
\text { - żadnego pogarszania dla dobrobytu przy- } \\
\text { szłych pokoleń, } \\
\text { - żadnego zanizenia stopnia ryzyka, } \\
\text { - żadnego przeliczania zagrożenia na po- } \\
\text { tencjalne korzyści, } \\
\text { - wprowadzenie obowiązku ubezpieczenia } \\
\text { na wypadek awarii, } \\
\text { - rozbudowa struktur ratunkowych i cen- } \\
\text { trów dowodzenia. }\end{array}$ \\
\hline
\end{tabular}

${ }^{*}$ Mtoe - ekwiwalent milionów ton ropy.

Zrównoważony rozwój wymaga też od przemysłu udoskonalenia poziomu wyjścia oraz zminimalizowania poziomu wejścia, a także produkowania jak najmniejszej ilości odpadów ${ }^{44}$. Jest to związane $\mathrm{z}$ ciągłym doskonaleniem i poszukiwaniem nowych technik i technologii nieszkodzących środowisku. Na uwagę zasługuje też koordynacja celów zrównoważonego rozwoju z planowaniem przestrzennym ${ }^{45}$. Planowanie przestrzenne w duchu zrównoważonego rozwoju, jest skutecznym narzędziem kreującym pożądany cywilizacyjnie system gospodarczy i przestrzenno-bytowy.

Inną potrzebą jest stopniowa, ale zasadnicza zmiana w systemie ekonomii światowej. Dominującym obecnie wskaźnikiem rozwoju społecznego i cywilizacyjnego, jest wskaźnik produktu narodowego brutto (PNB), opierający się na szybkim zużywaniu zasobów przyrody. Jest to miara „bieżącej pieniężnej wartości wszystkich dóbr i usług finalnych wytworzonych w danej gospodarce w określonym czasie" ${ }^{36}$. Stosuje się to kryteriom jako powszechny wskaźnik określania stylu i standardu życia poszczególnych społeczeństw światowych. Na początku lat dziewięćdziesiątych agendy ONZ zaproponowały nową miarę rozwoju społecznego. Zaproponowany indeks rozwoju społecznego (HDI - Human Development Index) ${ }^{47}$ opiera się na trzech składnikach:

1) długości oczekiwanego życia w momencie urodzenia,

2) poziomie wykształcenia obywateli, wiedzy i dostępie do oświaty oraz

3) produkcie krajowym brutto per capita,

Upowszechnienie tego wskaźnika w polityce i ekonomi światowej, mógłby stać się adekwatną weryfikacją rozwoju cywilizacyjnego. Wymaga to jednak

44 Por. D. Szaniawska, A. R. Szaniawski, Zrównoważony rozwój, „Ekonomia i Środowisko”, 1995, nr 2(7), s. 51.

45 Zob. A. SzPonar, Fizjografia urbanistyczna, Wyd. Naukowe PWN, Warszawa 2003, s. 245.

46 Wskaźniki ekorozwoju, pod red. T. Borys, Wyd. Ekonomia i Środowisko, Białystok 1999, s. 35.

47 Wskaźnik HDI jest złożeniem trzech różnych wskaźników, liczonym według metodologii zaproponowanej przez zespół badaczy z Uniwersytetu Oxford (USA). Por. Wskaźniki ekorozwoju..., dz. cyt., s. 56; S. Kozłowski, Ekorozwój - wyzwanie XXI wieku..., dz. cyt., s. 120, i. inni. 
zmiany dotychczasowej świadomości społeczności światowej i akceptacji go przez elity rządzące oraz światowy biznes.

W celu właściwej implementacji zasad zrównoważonego rozwoju, należy powziąć od zaraz szereg działań edukacyjnych i zmodyfikować dotychczas dominujący system wartości. Edukacja ekologiczna jest ważną metodą skutecznego wprowadzania w życie zasad zrównoważonego rozwoju. Edukacja ekologiczna ma za zadanie przestawić myślenia ludzi z pozycji „zdobywcy” na pozycję "partnera” środowiska naturalnego ${ }^{48}$. Niezbędny jest więc rozwój edukacji i promowanie rozwoju gospodarki opartej na wiedzy.

Nadrzędnym zadaniem szeroko rozumianej edukacji ekologicznej - prowadzonej nie tylko w szkołach i uczelniach wyższych, ale również przy zakładach pracy, organizacjach młodzieżowych i społecznych, w kościołach i związkach wyznaniowych - jest pilne wytłumaczenie i upowszechnienie pojęcia ekorozwoju jako alternatywnego stylu życia, zapewniającego nam i przyszłym pokoleniom właściwe warunki egzystencji. Młode pokolenie będzie żyło w silnie zinformatyzowanym środowisku - co jest też jednym z założeń ekorozwoju - i dlatego musi się uczyć kreatywnego myślenia, samodzielnego stawiania pytań i rozwiązywania problemów na bazie stopniowo poznawanej wiedzy, a także logicznego, własnego myślenia i wyciągania wniosków ${ }^{49}$.

Proces równoważenia rozwoju cywilizacyjnego, zakłada zmianę fundamentalnych postaw i zachowań człowieka ery przemysłowo-technicznej. Od strony aksjologiczno-etycznej, treść ekorozwoju staje się obowiązkiem moralnym wobec innych form życia (przyrody) i innych ludzi żyjących obecnie jak i w przyszłości${ }^{50}$. Zrównoważony rozwój wymaga etycznej dojrzałości i zasadniczego zwiększenia potencjału intelektualnego społeczności światowej oraz dalszego odpowiedniego rozwoju nauki i techniki ${ }^{51}$. Dla ekorozwojowej przemiany cywilizacyjnej, potrzebne jest „ewolucyjne zastąpienie dotychczasowych (...) form wzrostu kosztem otoczenia, jakościowo nowymi formami społeczno-gospodarczego życia i rozwoju razem ze społecznym i przyrodniczym otoczeniem" ${ }^{22}$. Zadanie to wydaje się być najtrud-

48 Por. D. СıсHY, Międzynarodowe i krajowe projekty edukacyjne przygotowaniem do zrównoważonego rozwoju, w: Współpraca międzynarodowa w edukacji ekologicznej. Materialy pokonferencyjne, Fundacja Centrum Edukacji Ekologicznej Wsi, Krosno 1996, s. 6; A. KowalaK, Świadomość ekologiczna a realizacja idei zrównoważonego rozwoju, w: III Konferencja, Współpraca Międzynarodowa w Edukacji Ekologicznej, pod red. A. Kowalak, Fundacja Centrum Edukacji Ekologicznej Wsi, Krosno 2000, s. 5.

49 Por. M. Nowicki, L. Rib be, Problemy ekorozwoju Polski, Agencja Reklamowo-Wyd. A. Grzegorczyk, Warszawa 2001, s. 179.

${ }_{50}$ Z. Hull, Dylematy i wymiary ekorozwoju..., art., cyt, s. 7.

${ }^{51}$ L. Michnowski, Megatrendy alternatywne. Ekorozwój albo zagłada ekologiczna, w: Ekorozwój. Jego istota i możliwości wdrożenia. Materialy pokonferencyjne. (Międzynarodowe targi ekologiczne - POLEKO '95), Poznań, 23 listopada 1995r., s. 35, (materiał powielony).

52 Apel Warszawski - przyjęty w 1993 r. w Warszawie na I Światowym Kongresie Uniwersalizmu, „Ekonomia i Środowisko”, 1994, nr 1(4), s. 164. 
niejsze do zrealizowania. Ale od jego wypełnienia zależeć będzie sukces zrównoważonego rozwoju i dalsze trwanie naszej cywilizacji.

\section{Zakończenie}

Przypuszczam, że przyszłość zrównoważonego rozwoju będzie zależała od natężenia katastrof, klęsk i zagrożeń środowiskowych, w tym od stopnia i skali wyczerpywania się surowców naturalnych. Będzie to w sposób naturalny dopingowało światową społeczność do większego zaangażowania się na rzecz alternatywnej wizji rozwoju cywilizacyjnego. Jak to starałem się wykazać w tym artykule, taką alternatywą, już wypracowaną i chyba nieźle przeanalizowano, jest idea sustainable development. Przyjmując ją za punkt odniesienia, roztaczamy nową panoramę stabilnego i trwałego rozwoju cywilizacyjnego wszystkich mieszkańców Ziemi.

Zrównoważony rozwój jest takim alternatywnym modelem bytowania i rozwoju cywilizacyjnego. Niestety, jak na razie ta zwerbalizowana koncepcja, ciągle lepiej prezentuje się $\mathrm{w}$ teorii niż praktyce. Istnieje szereg barier utrudniających wprowadzanie w życie zasad i metod zrównoważonego rozwoju. Wśród nich, bardzo istotne są przeszkody natury mentalnej i świadomościowej. W związku z tym, potrzebna jest najpierw dobra wola naukowców, polityków, strategów i ekspertów od rozwoju społeczno-gospodarczego oraz osób sprawujących władzę na różnych szczeblach, od organizacji międzynarodowych, poprzez rządy i gospodarki poszczególnych krajów, do samorządów terytorialnych i lokalnych. Istnieje też konieczność ciągłego rozwoju intelektualnego, prowadzącego do lepszego zrozumienia tej koncepcji i wykształcenia u ludzi świadomości i odpowiedzialności za środowisko życia i dalszy rozwój cywilizacyjny.

Postęp cywilizacyjny zawdzięczamy szukaniu nowych dróg wzbogacania się i udoskonalania naszych zachowań. Mądrość polega na tym, żeby tych rozwiązań nie szukać w ostatniej chwili. Możemy ustrzec się wielu kryzysów jeśli potrafimy w porę je przewidzieć i zgodnie stawić im czoła. Intelektualna analiza koncepcji zrównoważonego rozwoju, jest prowadzona w różnych kierunkach. Otwiera to tym samym nową panoramę rozwoju cywilizacyjnego na przyszłość. Trzeba tylko z tej możliwości mądrze i odpowiedzialnie skorzystać. Uważam, że pomimo swoich braków, a tudzież i krytyki, koncepcja „zrównoważonego rozwoju” zasługuje na uwagę jako swoista alternatywa dalszego rozwoju cywilizacyjnego. 


\title{
Panorama cywilizacji zrównoważonego rozwoju
}

\author{
STRESZCZENIE
}

Artykuł dotyczy koncepcji zrównoważonego rozwoju (sustainable development) osadzonej w kontekście zmian kulturowych i cywilizacyjnych. Można ją traktować jako alternatywę i nową panoramę, otwierającą perspektywiczne widoki na dalszy trwały i zrównoważony rozwój cywilizacyjny.

Idea ta, jest globalną strategią rozwoju. Polega na włączeniu środowiska naturalnego do rozwoju społeczno-gospodarczego regionu, kraju czy w ujęciu globalnym całego świata. Zakłada trwałą poprawę jakości życia współczesnych i przyszłych pokoleń, co integralnie łączy się z poprawą stanu środowiska człowieka. Wskazuje też na potrzebę rozwoju duchowego człowieka i zamianę celów rozwojowych z materialnych na niematerialne. W tych ogólnych założeniach i celach, zrównoważony rozwój napotyka na wiele praktycznych i mentalnych problemów, które hamują, bądź wręcz uniemożliwiają efektywne wprowadzanie tej koncepcji w życie.

\section{Panorama of the civilization of the sustainable development}

\author{
SUMMARY
}

The article is about the conception of the sustainable development settled in the context of cultural and civilization changes. It can be taken as an alternative of the further civilization development.

The conception is a global strategy of the development. It relies on the including of the natural environment into the social and economic development of a region, country or, in a global perspective, of the whole world. It assumes a long-lasting improvement of the quality of life of the present and future generations which is integrally associated with an environmental improvement. It also shows the necessity of the spiritual growth and changes of the material aims of the development into immaterial ones. In all these aims and assumptions there are a lot of practical and mental problems in the sphere of the sustainable development which retard and even make it impossible to put these conceptions effectively into life. 